\title{
Emergence of Abagusii Diaspora in Kenya's South Rift, 1895- 2007: Opportunities and Challenges
}

\author{
Gladys Nyaboke Achoki* $\quad$ Rev. Fr. Kizito Muchanga Lusambili James Runaku \\ Masinde Muliro University of Science and Technology, P.O., Box 190-50100. Kakamega, Kenya
}

\begin{abstract}
Migration is a spatial phenomenon involving movement of people between distinct places, locations imbued with meaning and power and it has been there since time immemorial. It specifically refers to people changing their places of residence, where they live on a habitual basis, embracing not only their actual physical structures, but also in some sense the wider community in which they live. This study focused on the Abagusii migration patterns specifically to the South Rift (SR), Kericho County. It acknowledges the fact that their emergence in the diaspora just like any other ethnic group in Kenya, came to existence in the pre-colonial, colonial and post-independence period. The main aim of the study was to establish their movement, settlement, challenges, and opportunities they encountered in SR between 1895 and 2007. This research addressed the emergence of Abagusii before colonialism. The study focused on the period from 1895 because it was the genesis of the British colonial policies, which witnessed forceful movement of not only the Abagusii, but also other Kenyan communities. The study adopted qualitative research design where non-probability sampling techniques (such as opportunity sampling, snowball sampling, and purposive sampling) were used. Content analysis was done from documents in the Kenya National Archives (KNA) that were corroborated with information from field observations and interview schedules.
\end{abstract}

Keywords: Migrations, Abagusii, Diaspora, South Rift

DOI: $10.7176 / \mathrm{HRL} / 50-03$

Publication date: November $30^{\text {th }} 2019$

\section{Introduction}

Brown (2007); Cohen (2005); Sheffer (1986) \& Prothero, (1986) have attempted to explain the terms, migrations and diaspora. Their explanations have been used in this study, as to what is the meaning of migration and diaspora. It needs to be noted that human migrations have been there since the beginning of civilization. These migrations were necessitated by among others, various factors such as social, political, and economic. these migrations have therefore, not only brought changes to the world politically, economically, socially and culturally but also redefined boundaries, compressed ideas of space and reinterpreted the perception of nation, home and identity.

Prothero, (1986) depicts relocation in Africa as including three progressive stages: developments which occurred previously however which have stopped to exist; developments that have persevered from the past into the present; and developments that have created in the ongoing past. The remainder of these cases straightforwardly concerns this investigation as it incorporates changeless country rustic relocation started in frontier Kenya as one impact of the British provincial monetary framework. The term diaspora mean any gathering of vagrants forever settled outside their place of starting point. Cohen, 2004 proposed a typology of diasporas every one of which has been brought about by an alternate arrangement of encouraging conditions. This outcome in an assortment of social settings, legends, and meanings of solidarity. He named them as; Victim diasporas (Africans and Americans), Labor and supreme diasporas (Indentured Indian and British), Trade diasporas (Chinese and Lebanese), Homeland diasporas (Sikhs and Zionists), Cultural diasporas (Caribbeans) and Globalization diasporas (International movement). Cohen encourages that these sorts may cover and may change their character after some time. While alluding to present day Diasporas, Sheffer (1986) has proposed another meaning of diaspora which he ordered as current. He portrays them as ethnic minority gatherings of solid, nostalgic, and material connections with their nations of origin (their countries). Agreeing with Brown (2007), he takes note that diaspora is a social developed established on inclination, cognizance, memory, folklore, history, significant accounts, bunch character, longings, and dreams, metaphorical and virtual components all of which assume a job in building up a diaspora reality.

\section{Africa Diaspora}

Wickra masekara, (2009) hypothesizes that Africa had for some time been influenced by powers related with servitude, expansionism, and globalization making a circumstance in which African people were scattered in various areas of the world. It is along these lines, critical to recognize the old (conventional) and the new diaspora, who are more in the idea of transnational networks as referenced previously. The African Diasporas can be characterized comprehensively into two classifications: Africans in America, the UK, Brazil, Latin America, and Caribbean as a result of automatic relocation. There is additionally the new African foreigner, primarily in North America and Europe and to a littler degree in Australia and Japan, among others, due to intentional relocation for training or business.

As indicated by the World Bank (2007), the official gauge of recorded 'intentional' African foreigners in 
North America and Europe is around 3,000,000 (one million in the United States, 282,600 in Canada and 1.7 million in Europe). The figure for Europe does exclude workers from North Africa. By and by, this investigation centers around the movements and settlement of the Abagusii in South Rift (SR) receiving the definitions as portrayed before.

As indicated by Ochieng' (1974) the investigation of the relocations of old individuals can't be kept to our present-day national or commonplace limits. It is likewise portrayed by populace issue that confounded the entire zone every which way, for example, the individuals who moved from Mozambique, Malawi, and Zambia into Tanzania and past. Others moved from the North into East Africa, others from Indian Ocean coastlands into the inside, while others moved from present day Uganda into Western Kenya.

Kenya as a country has experienced this diaspora phenomenon up to the present day. For instance, externally, various groups of people have found their way into Kenya. This is demonstrated through historical records as contained in the 1962 census during the colonial period. These external groups include the Europeans, Asian and Africans who were already in diaspora in Kenya (Kenya population census Report 1962).

Internally it needs to be noted too that Kenyan ethnic communities have been in constant migrations making them to be in diaspora. Because of these ongoing migrations within Kenya,Abagusii people have not been spared either.

\section{Abagusii People}

According to Ochieng' (1974) Abagusii occupied the most Southern portion of the cool fertile western section of the Kenya Highlands. Their language places them within the family of Bantu-speaking majority of sub-equatorial Africa. They inhabit two counties, Kisii and Nyamira in western Kenya. Gusii is the fond reference to their homeland and Mogusii is their eponymous founder. The home area is sandwiched between the Kipsigis, Nandi, Maasai and the Luo ethnic groups. They are related to the Tende (Abakuria). The 1989 National Census recorded the Abagusii people at 1.3 million and population densities ranged from 200 to over 600 per square kilometer. This population, increase by three percent per year. In 2009 Kenya national population census, the Abagusii constituted the country's sixth largest ethnic group, comprising about seven percent of the national population. The population was 2.2 million people. To this day, they have a reputation of being tough, emotionally labile, resilient, risk takers and very industrious.

Gusii land covers 2230.4 square kilometers according to Kenya Constitution (2010). It is located in western Kenya and about thirty miles (fifty' kilometers) east of Lake Victoria. It is found along latitude $0{ }^{\circ} 45^{\circ}$ South and longitude $34^{\circ} 50^{\circ}$ east. The area receives ample rainfall throughout the year besides having rich soils. As a result, the area is agriculturally productive with a teeming human population. Tea, coffee, pyrethrum, and bananas are some of the crops cultivated in the area. Today, livestock production thrives in Gusii land as well. The area is a rolling, hilly landscape on a plain reaching an altitude of 3900 feet above sea level $(1,190 \mathrm{~m})$ in the northwest tern corner of the territory and 6988 feet $(2,130 \mathrm{~m})$ in the central highlands. The mean maximum temperature ranges from $28.4{ }^{\circ} \mathrm{Cat}$ the lowest altitudes to $22.8^{\circ} \mathrm{Cat}$ the highest elevations and the average minimum temperatures is $16.4^{\circ} \mathrm{Celsius} 9.8^{\circ} \mathrm{C}$ respectively (County yearly report; https//:www.kisii.go.ke).

Chavasu (1997) concurs with Ochieng' (1974) about the migration of the Abagusii and the Logoli in particular, originally they migrated into Nyanza from a homeland they identify as Misri (presumably in the River Nile Valley in Egypt) to the North of Mt Elgon at the beginning of the $16^{\text {th }}$ century. The Abagusii talk of Mogusii as the founder of their society and the person after whom their ethnic group is named. History also has it that Mogusii's father was Osogo, son of Moluguhia, son of Kigoma, son of Riabiaka, who was the son of Kintu. Kintu led the migration from the land of Misri to the foothills of Mount Elgon, where they stayed for four generations before dispersing to various directions due to droughts and other natural pestilences. Abagusii traditions also indicate that Moluguhia, the grandfather of Mogusii, had a number of sons who founded some of the Baluyia subgroups or clans. Some of the sons of Mogusii were Osogo and Mogikoyo. Osogo's descendants are said to have founded the Abagusii, Kuria, Logoli and Suba ethnic groups while Mogikoyo gave raise to Kikuyu, the Embu, Kamba and Meru groups, (Ochieng', 1986). This migration concurred with what the focus group discussion mentioned on the field, how they moved from Misri (Egypt). From Misri they moved to Mt Elgon with the Mulagoli only to separate later in Kisumu.

Ogot (1976) notes that, the Abagusii oral tradition indicate that, they were the same people as the Kuria, the Logoli, the Bukusu, the Suba of south Nyanza, the Kikuyu, the Meru, the Embu and the Kamba. The Gusii oral traditions also state that from Msiri they were together with Ganda and Soga. The two ethnic groups branched off from the rest of the migrants around Mt. Elgon, in the South Westerly direction. The Kikuyu, Meru, Embu and Kamba are said to have travelled eastwards toward what is now the central highlands of Kenya while Bukusu appear to have remained around Mount Elgon.

According to Ogot (1976), linguists like Whitley and Greenberg, and anthropologists like Hobley, Johnston, and Oliver, who have studied the Abagusii and other Bantu languages, have agreed that, the Abagusii, Logoli, Kuria, Kikuyu, Embu, Kamba and Meru languages are closely related. They argue that from Misri they all migrated to the foothills of Mount Elgon where the final dispersal took place. 
Ochieng (1986) notes that, the remaining clusters, Abagusii, Kuria, Suba and Logoli migrated southwards following the course of river Nzoia, arriving on the Eastern shores of Lake Victoria around 1490-1520. Turning east, they travelled along the Lakeshores and eventually settled at Goye Bay in Yimbo Kadimo location where Mogusii and Mulogoli, the respective eponymous founders of the Abagusii and Logoli societies were born. From here, their homestead spread to Ulowa, Sare, Ungejra, at the foot of Ramogi Hills, where the first wave of the Luo immigration into West Kenya found them.

Ochieng (1986) extents that, Abagusii economic and social institutions underwent a fundamental transformation in the period between 1520 and 1755 as they established themselves in the lake region where they spent about two generations. Due to constant migration, Abagusii culture became inevitably a mixture of various influences, combining original Bantu elements with aspects borrowed from or imposed by contacts with Nilotic speaking people, notably the Luo, Maasai and Kipsigis. After prolonged cattle rustling, conflict between Abagusii and the Luo were frequent. They posed a big security risk and infiltration, and other Bantu groups from northeastern around Lake Victoria like Munje, Nzaba, Maswa, Boko Ini and Lungo who were also a threat to Abagusii. The Abagusii and Logoli were compelled to move to Alego, Gangu then to Kisumu led by Mogusii and Mulogoli. It is at Kisumu where Mogusii disappeared [either he died or too old to command general respect as group leader]. Nyakomogendi, the mother of Mogusii also died in Kisumu settlement. Because of drought and famine, they left Kisumu and eventually migrated to Kano plains led by some warriors such as Oibabe, Mobassi, Omugesero, Mochorwa and Kimanyi where they settled between 1620 and 1755, (Ochieng 1986).

While at Kisumu, the Logoli broke off and travelled northwards into Kiti Mikaye then to Maseno and to their present homeland. Their outward movement was probably due to drought and famine.

The Abagusii settlement in Kano plains probably lasted seven generations between A.D 1640 and 1755 (Ochieng', 1986; Ogot, 1976). They settled by the lakeshore from Dunga to Nduru and spread into the interior along streams. It was in this period that the Abagusii economic and social institutions experienced a notable transformation. It not only witnessed the expansion and transformation of individual family units into small but distinct clans, but also the evolution of small groups. Clan leaders came into existence at this point. Around this period the Abagusii social institutions such as sectional totems, clans and, sub- national structures emerged.

Ochieng' (1986) maintains that, Abagusii interacted with other people in the plains in a variety of ways acquiring from them iron working and fishing technology. Ogot also indicates that the economy of the Abagusii during their stay in Kano was mixed. They cultivated finger millet, which was grown together with sorghum, beans and sweet potatoes and used cattle meat for food, drank milk and cattle-blood. They also ate roots, yams, pumpkins, vegetables, fish, birds and fruits like strawberry, raspberry, raised berry, lily berry and cape berry. They hunted the buffalo, bushbuck, wildebeest, and the rabbit among many others.

One of the Key informants reported that:

As they were moving, there was a lot of mixing with other ethnic communities, they learned new things from them such as iron working, fishing technology and their culture and religion was mixed too, hence started practicing mixed farming (KII, Clan elder, $8^{\text {th }}$ August, 2018).

Ng`ang a (2006) says that about A.D 1755 Abagusii moved out of Kano plains, being overwhelmed by Luo raiders and spearmen and decided to look for peace and security elsewhere. From Kano plains the Abagusii moved in four major and distinct groups. The expansion into the highlands from the lowland plains necessitated a change in their economy and society. They first stopped at Gososia near Ngoino the present day north Mugirango. Here, their oral tradition states that the soil was not good to produce finger millet and they were so close to the enemy (Luo), therefore some moved to Nyamira as others remained behind, they found Nyamira thick wooded highland. The wet and cold conditions of the highlands killed many of their people and forced some of them to move to south Mugirango where the climate was warmer. However, the Maasai forced them to retrace their steps back into the highland. They finally settled at Kiogoro in Nyaribari then to South Kitutu and eventually expanding to North Mugirango. One village elder indicated that their grandparents used to plant crops and rear animals.

Ogot (1976) and Ng`ang`a (2006) state that from Gososia (North Mugirango) another group moved several days to Biego then they migrated north-eastward to Kabianga in Belgut. With better iron weapons, the Abagusii were able to expand at the expense of the Kalenjins, Sirkwa, Dorobo and Maasai into areas of present day Kericho. This expansion into the highlands from lowland plains also necessitated change in their economic and social organization.

\section{Abagusii Migration to South Rift}

The Abagusii extended to Kabianga (meaning, an inhabitable place in Kericho), here the climate was wet and cold throughout the year, they tried to plant millet and pumpkins in the new gardens but the crops did not do well and many of their animals died. Completely alarmed by the rate at which their people and flocks were dying, the Abagusii decided that the devils and spirits of whoever had originally occupied Belgut were against them. During the data collection period, the researcher came across a remnant of the migration who emphasized as follows: 
When we arrived here at Kabinga, the place was wet and a lot of water but many of our people and our animals died. People thought that the spirits of the dead are following us, so most of them moved out of the place (KII, Clan elder, $3^{\text {rd }}$ August, 2018).

They then moved only a few miles eastward to Kericho, where they encountered the Maasai. Living alongside Abagusii were Maasai together with the Kipsigis, who are part of the Kalenjin, their meetings were not always peaceful. There were constant fights between these groups. This is where the Abagusii killed the Maasai war leader, Ole Kericho (after whom, by one mind Kericho town is named) (Ochieng 1986.) One of the informants asserted that the battle took too long hence; there was loss of life and animals.

The Kipsigis raided both the Maasai and Abagusii for cattle. As a result, the Maasai moved away from Buret. The Abagusii put up a spirited fight and kept the Kipsigis at bay for some time. The Abagusii built heavy stone fortifications called "orwaki" round their villages, which were further secured on the outside by deep trenches. A key informant reported that,

At night all cattle were brought here and men and their warriors used to sleep

outside to keep an eye over the animals (KII, Church elder, 7th August, 2018).

Because of several ambushes and counter ambushes, the Abagusii were forced to migrate southwards beyond present day Sotik. However, even here the Kipsigis did not leave them in peace. Thus in the following centuries of migration, the Abagusii settled in the present Gusii highland (later on was referred to as Gusiiland) during the closing of the nineteenth century (Omwoyo 1990). It notes that the entire Gusiiland was one until 1961 and by 1988 it was divided into Kisii and Nyamira.

From Kano plains as Abagusii were moving to the highlands, some group of Abagusii moved to Kabianga where they settled for some time. despite the fact that their people, animals and crops died there, still some of them remained behind to form the group which is found in SR. On the other hand, some Abagusii found themselves in SR as they were bartered out by their parents during great famine called Amakogirio for food to Kipsigis land,

\section{Theoretical Framework}

The study was anchored on historical materialist theory that is relevant to the study because it focuses on the social reality and the economic structure of a particular society in this case the Abagusii society. It goes further and explains how different groups of people relate to economic resource of their society and ways of production. The Abagusii who went and lived in diaspora were an aftermath of the change of economy and social interaction from pre-colonial, colonial, and post-colonial era. That is the coming of the British Colonialists into Kenya who came with capitalist economy and land policies which led to land alienation and displacement of people contributed greatly to the major migrations and settlement of Abagusii in the new lands "schemes".

\section{Methodology}

The study adopted qualitative design and non-probability sampling techniques where by knowledgeable persons on the topic of study were identified. Non- probability sampling was applied in selecting the sample of the study included opportunity sampling, snowball sampling and purposive sampling. Primary data were collected using semi-structured interview and observations. The transcribed data was grouped into major themes and sub-themes based on the similarities and differences in the responses. Both the secondary and primary sources of data were subjected to criticism to test the relevance and accuracy of the information that was identified as appropriate for this study.

\section{Key Findings}

Politically, there was incitement from some political leaders based on the local scarce valuable resources that the two communities were competing over such as land and livestock. This led to the movement, spread and settlement of Abagusii in diaspora. Politics of exclusion was also identified where the Kipsigis were perceived to have received more privileges from the national government than the Abagusii. This made the Abagusii to develop bitter sentiments and hatred against the Kipsigis as they felt marginalized, and this is where those who were willing decided to go and look for those privileges such as the social amenities in Kipsigis land where they ended up living in diaspora. The two communities (the Kipsigis and Abagusii in diaspora) were in conflicts due to the reintroduction of multiparty politics where political parties' championed ethnic sentiments, which in turn led to political patronage, based on party affiliations.

Other than politics, other factors were identified to be behind the migration, spread, and settlement of the Abagusii in diaspora. Raiding of livestock was identified to be the major factor behind the conflict between the two communities as it had some cultural backing in the rites of passage of initiation and marriage between the two communities, which brought about movement of the Abagusii. Land was also identified to be an important resource that the two communities were competing for. This was because of the cultural and economic value attached to land in both communities. The colonial policies such as the Kipande system, labour laws, and squatter system, 
among others also prompted the movement of the Abagusii into SR during the colonial period. This is because Abagusii were trying to run away from the oppressive colonial policies that were imposed. Unemployment also contributed to the migration and settlement of Abagusii in diaspora in SR. The unemployed masses are the larger population that constitutes the Abagusii in diaspora as they were the ones who went to Kipsigis land in search of job opportunities so as to earn a living and better their lives. Due to the colonial white settlers who had large farms and plantations (that they had grabbed the fertile land from the Kipsigis), the demand for unskilled and semiskilled labour was very high and that meant that the Abagusii in diaspora were able to easily secure the jobs in the Kipsigis land. They also secured a place for living as squatters in their employers' farms as they were saving money to buy their own farms.

There were some socio economic challenges that the Abagusii in diaspora faced. Some of these challenges include; displacement of people from communities, stealing of chicken and household items, attack of diseases such as small pox and jiggers. They also faced lack of basic needs such as; shelter, clothing and food. Some of these problems like lack of food were solved by the D.O (who was a Gusii) who gave them some food and a place to farm temporarily in order to get some food. Most of them especially the children did not get education thus ending up as prostitutes and bar tenders. All these challenges led to increase in poverty in the region hence poor living standards. There was water problem until water was supplied by the town council at two Kenya shillings for 20 liters. Other challenges they faced include, selling beer by young children, witchcraft, congestion, language barrier, unconducive environment,/harsh environment, cattle raiding, poor transport and communication network, distant working places, and disruption of economic activities like trade and agriculture which also increased poverty in the region due to displacement.

Though they were faced with many challenges, they enjoyed some opportunities which some of them could not access or get in their ancestral land. These opportunities came after their settlement in diaspora and they were discussed in two categories; that is in terms of the socio- economic and political opportunities. Some of these opportunities included availability basic need like food, shelter and clothes, accessibility of social amenities such as school and hospitals, intermarriages freedom, development of good relationship with the Kipsigis and other communities in diaspora. In addition to that, the Abagusii in diaspora were able to secure political leaderships positions like chiefs, district officers, got their own lands which letter on were given their own title deeds and also the ability to conduct their farming activities which was their economic activities.

\section{Summary}

To assess the emergence of the Abagusii in pre-colonial period, the research looked at their migration from Misri being their cradle land into Mount Elgon their first dispersal point in Kenya. As they were moving, they were looking for fertile land for farming. The researchers also looked at other aspects that made the Abagusii to migrate in the pre-colonial period. This included the internal and external dynamics that influenced their political, economic, and social structures. From Mount Elgon, they moved to Kisumu and due to unfavorable climatic conditions, they continued to move to Kano plains. They stayed in Kano plains for some generations but later on, the incoming Luos chased them then some of the Abagusii moved to Gusii highland, which is their present homeland while others moved to Kabianga in SR.

\section{Conclusion}

An analysis of the history and activities of the Abagusii who moved out of Gusii and settled in South Rift, between 1895 and 2007 has been summarized. The year 1895 is important being a year when formal British colonialism started and $2007 / 2008$ being the dark years in the Kenyan history because of post-election violence. In this work, a number of issues like political, economic and social issues have been mentioned which need to be re-emphasized in this conclusion. This research therefore, found out that the following political factors made the Abagusii move to SR for example shifting of power from the colonial masters to black natives, prominent Gusii leaders in government and those who worked S.Social factors include social amenities such as schools and hospitals, security, presence of areas of settlement in diaspora, overpopulation back at ancenstral home. Economic factors such as buying land through shares, entrepreneurship and, employment in the coffee and tea plantations.

\section{Recommendation}

Sensitization on the importance of peace should be done on the people in the area under study and encouraged to interact with each other peacefully. This can be done through the establishment of more multi- ethnic markets by the county governments where the two communities Gusii in diaspora and Kipsigis in South Rift will be interacting in addition to trading activities. In the process, they can be encouraged to engage themselves in merry-go rounds. These will help them understand each other more.

The county governments should organize cultural and sporting activities to promote good relations, bonding, nurture talent and keep the idle youth busy. These avenues can be used to promote peace and better relations between the two communities and better understanding. The government should also organize seminars and 
conferences within the place of residence of Abagusii in diaspora within SR.

\section{REFERENCES}

Brown, J.M., (2007). Global South Asians: Introducing the Modern Diaspora. Cambridge University Press. USA. Chavasu,H.O,(1997)British Colonialism and the Making of the Maragoli Diaspora in Western Kenya, 1895 to 1963 A masters of Philosophy, thesis Moi University, Kenya

Cohen, R. (2005). Encyclopaedia of Post-Colonial Studies. Westport: Greenwood Press. J. C. Hawley, Ed Ng'ang'a, W. (2006). Kenya's Ethnic Communities. Gutundu publishers limited. Nairobi. Kenya.

Ochieng'. W.R., (1974). A Pre-Colonial History of Abagusii of Western Kenya from C.A.D 1500- 1914. East African Literature Bureau, Nairobi.

(1974). Kenya's People of the South-Western Highlands- Gusi. Nairobi: Evans Brothers.

(1986). Kenya's People of the South-Western Highlands- Gusii Evans Brothers. Nairobi

Ogot. B.A. (1976). Kenya before 1900. Nairobi, Kenya. East Africa Publishing house.

Omwoyo. S.M., (1990). "The Colonial Transformation of Gusii Agriculture". M.A. thesis. Kenyatta University.

Prothero.R.M. (1986). "Migration in Tropical Africa". (J. C. Okonjo, Ed.) Longman. London.

Sheffer, G. (1986). Modern Diasporas in International Politics. London and Sydney:Helm

Shillington. K. (1995). History of Africa. Malayasia. Macmillan

Wickramasekara, P. (2009). Diasporas and Development: Perspective on Definition and Contributions/Labour office, Social Protection Sector, International Migration Programme.-Geneva: ILO, 200946 P.C (Perspective on Labour Mi

World Bank (2007. Mobilizing the African Diaspora for the Development, Concept Note AFTCD. Washington DC. 